\title{
Augmentation of Reverse Arthus Reaction by Mast Cells in Mice
}

Yan Zhang, Bernard F. Ramos, and Barbara A. Jakschik

Department of Pharmacology, Washington University School of Medicine, St. Louis, Missouri 63110

\begin{abstract}
Immune complex-induced injury is an important pathogenic factor in antibody-mediated nephritis, systemic lupus erythematosus, rheumatoid arthritis, and other diseases. In this study we investigated the role mast cells in immune complex-mediated injury in mouse skin. Reverse Arthus reaction was induced in mast cell-deficient $\mathrm{WBB} \mathrm{F}_{\mathbf{1}}-\mathrm{W} / \mathrm{W}^{*}$ mice and their congenic controls $\left(\mathrm{WBB} \mathrm{F}_{1}-+/+\right)$. Serial skin sections were evaluated for neutrophil infiltration, edema, and hemorrhage. In $\mathrm{WBB} \mathrm{F}_{1}-\mathrm{W} / \mathrm{W}^{\mathbf{v}}$ mice the neutrophil influx was only $40 \%$ and edema $60 \%$ of that in congenic controls. Hemorrhage was also significantly reduced in the mast cell-deficient mice. After mast cell reconstitution, the magnitude of the reaction in $\mathrm{WBB} \mathrm{F}_{1}-\mathrm{W} / \mathrm{W}^{\boldsymbol{}}$ was equivalent to that in $\mathrm{WBB}$ w $\mathrm{F}_{1}-+/+$ mice. Mast cell release in reverse Arthus reaction was evaluated by measuring fluorescence intensity after avidin-FITC staining of mast cell granules. There was a $70 \%$ decrease in fluorescence intensity. The 5-lipoxygenase inhibitor A-63162 significantly decreased neutrophil accumulation (40\%), edema (60\%), and hemorrhage in $\mathrm{WBB6F}_{1}-+/+$, but not in mast cell-deficient mice. Mast cell reconstitution of $W B B 6 F_{1}-W / W^{\top}$ mice restored the effect of A-63162. The results indicate that mast cells and their mediators, including leukotrienes, make an important contribution to reverse Arthus reaction. (J. Clin. Invest. 1991. 88:841-846.) Key words: leukotriene • immune complex-mediated injury • 5-lipoxygenase inhibitor • inflammation • PMN infiltration
\end{abstract}

\section{Introduction}

The formation of immune complexes and their deposition in tissues precipitate an acute inflammatory reaction. Immune complex-induced injury has been implicated in a variety of human diseases, such as systemic lupus erythematosus, rheumatoid arthritis, antibody-mediated glomerulonephritis, and other conditions. Reverse passive Arthus reaction has been extensively studied as a model of immune complex-mediated tissue injury. The reaction is induced by injecting the antigen i.v. followed by the local administration of the antibody. The resulting lesion is characterized by histological changes, includ-

Preliminary results were presented at the meeting of the Federation of American Societies of Experimental Biology, 1-5 April 1990, Washington, DC.

Address correspondence and reprint requests to Dr. Jakschik, Department of Pharmacology, Washington University School of Medicine, 660 South Euclid Ave., St. Louis, MO 63110.

Received for publication 13 November 1990 and in revised form 3 June 1991

J. Clin. Invest.

(c) The American Society for Clinical Investigation, Inc.

$0021-9738 / 91 / 09 / 0841 / 06 \$ 2.00$

Volume 88, September 1991, 841-846 ing leukocyte infiltration, edema, tissue necrosis, and hemorrhage. Neutrophils and activation of the complement pathway are essential for the reaction (1). However, the cell responsible for the initiation of leukocyte elicitation and edema is not yet well established. Mast cells are strategically located in the vicinity of blood vessels. Upon stimulation they release a variety of proinflammatory mediators, such as histamine, platelet-activating factor, cyclooxygenase products, and leukotrienes (LT). ${ }^{1}$ Mast cells are well characterized for their role in immediate hypersensitivity reaction. Other functions of mast cells have not been extensively studied. Galli and Kitamura have published a comprehensive discussion of the value of mast cell-deficient mice for the investigation of the role of mast cells in biological responses (2). Galli and his co-workers have shown the importance of mast cells in the expression of such inflammatory processes as leukocyte infiltration, edema, and fibrin deposition in cutaneous anaphylaxis, and after application of phorbol myristate acetate and substance $P(3-5)$. At the same time we initiated studies investigating the role of mast cells in inflammation other than immediate hypersensitivity. We found that mast cells contribute to the neutrophil recruitment in thioglycollate (6) and immune complex-induced peritonitis (7). It has been reported that mast cells play an important role in antigen-induced arthritis (8).

The present work investigates the role of mast cells in the development of reverse Arthus reaction in the skin using mast cell-deficient $\mathrm{WBB} \mathrm{F}_{1}-\mathrm{W} / \mathrm{W}^{\mathrm{v}}$ mice and their congenic controls. The PMN infiltration, edema, and hemorrhage were evaluated. The results indicate that mast cells contribute to these inflammatory parameters. Studies with the 5-lipoxygenase inhibitor A- 63162 suggest that leukotrienes released by mast cells mediate these processes.

\section{Methods}

Materials. Chicken egg albumin, hematoxylin, eosin, alcian blue, safranin O, and triethylenediamine were purchased from Sigma Chemical Co. (St. Louis, MO), avidin-FITC from Zymed Laboratories, Inc. (San Francisco, CA), rabbit anti-chicken egg albumin (IgG fraction) from Cappel Research Products (Durham, NC), PBS, RPMI-1640, L-glutamine, nonessential amino acids, sodium pyruvate, penicillin, and streptomycin from the Tissue Culture Support Center of Washington University (St. Louis, MO). The 5-lipoxygenase inhibitor A-63162 was a gift of Dr. R. Bell (Abbott Laboratories, Abbott Park, IL).

Mice. Mast cell-deficient $\mathrm{WBB} \mathrm{F}_{1}-\mathrm{W} / \mathrm{W}^{\mathrm{v}}\left(\mathrm{W} / \mathrm{W}^{\mathrm{v}}\right)$ mice and their normal littermates, WBB6F $_{1}-+/+(+/+)$, were purchased from Jackson Laboratory (Bar Harbor, ME). These mice were used when they were $90 \mathrm{~d}$ or older. $\mathrm{W} / \mathrm{W}^{\mathrm{v}}$ mice are established for their profound deficiency in mast cells (9). These mice also have macrocytic anemia and decreased numbers of granulocytes and megakaryocytes in the bone marrow. However, the number of granulocytes and platelets in the

1. Abbreviations used in this paper: Ab, antibody; ELAM-1, endothelial-leukocyte adhesion molecule-1; ICAM-1, intercellular adhesion molecule-1; LT, leukotriene; $\mathrm{W} / \mathrm{W}^{\mathrm{v}}$, $\mathrm{WBB} \mathrm{F}_{1}-\mathrm{W} / \mathrm{W}^{\mathrm{v}} ;++/+\mathrm{WBB}^{\mathrm{F}} \mathrm{F}_{1-}$ $+/+$. 
blood of adult $\mathrm{W} / \mathrm{W}^{\mathrm{v}}$ mice is normal $(10,11)$. Their mast cell deficiency and anemia can be repaired by bone marrow transplantation from $\mathrm{WBB} \mathrm{F}_{1}-+/+$ mice (9). However, administration of mast cells alleviates only the mast cell deficiency $(7,12)$. The ability of these mice to selectively undergo systemic or local repair of their mast cell deficiency renders these mutants a useful tool for the investigation of mast cell functions in vivo.

Induction and evaluation of the inflammatory reaction. Mice were injected i.v. with chicken ovalbumin $(20 \mathrm{mg} / \mathrm{kg})$, followed by antichicken ovalbumin antibody (Ab), IgG fraction, i.d. on shaven backs, 10,30 , and $100 \mu \mathrm{g} /$ site, two injections per dose. At the times indicated after the injection of $A b$, skin specimens were fixed in $10 \%$ phosphate buffered formalin and embedded in paraffin. Serial skin sections (10 $\mu \mathrm{m}$ ) were stained with hematoxylin and eosin and evaluated microscopically for PMN infiltration, hemorrhage, and edema. The examination was performed in a blinded fashion. Equivalent results were observed by two different individuals. PMN infiltration was assessed either by counting PMN per section or in arbitrary units. PMN density for four to nine sections per injection site was averaged. Arbitrary units were used to evaluate most of the experiments because PMN infiltration with $100 \mu \mathrm{g} / \mathrm{site}$ of $\mathrm{Ab}$ in $+/+$ mice was too dense to perform an actual PMN count. A scale of 1 to 8 was chosen, 8 indicating the highest PMN density. The arbitrary units were established by counting the PMN in some sections in which individual PMN could be distinguished and by allocating certain ranges to the lower units $(1:<100,2: 100-400,3: 400$ 700, 4:700-1,000 PMN/section). The remaining higher units were assigned depending on the size of the patches filled with PMN. Hemorrhage was also assessed in arbitrary units, $1-5$. They were established by counting erythrocytes in some sections and allocating ranges (1:100$200,2: 200-400,3: 400-600 \mathrm{RBC}$ per section). The higher units were assigned depending on the size of the patches filled with erythrocytes. Edema was evaluated by measuring microscopically the thickness (millimeters) of mounted cross-sectioned skin specimens with a micrometer.

Mast cell reconstitution of $W / W^{\nu}$ mice. Bone marrow cells harvested from femurs of male $\mathrm{WBB} \mathrm{F}_{1}-+/+$ mice were cultured and differentiated into mast cells as described previously (13). These mast cells ( $>98 \%$ purity) were injected i.d. (multiple sites, $1 \times 10^{6}$ per site) into $\mathrm{W} / \mathrm{W}^{\mathrm{v}}$ mice. The mast cell-repleted sites were marked with India ink and challenged 7-8 wk after mast cell repletion.

Mast cell degranulation study. Skin sections from $8 \mathrm{~h}$ challenged $(100 \mu \mathrm{g} \mathrm{Ab})$ sites (with or without pretreatment with A-63162, 100 $\mathrm{mg} / \mathrm{kg})$ were stained with avidin-FITC $(6.25 \mu \mathrm{g} / \mathrm{ml})$ for $2 \mathrm{~h}$ and then mounted in buffered glycerol, $30 \mathrm{mM}$ triethylenediamine, $\mathrm{pH}$ 8.6. Avidin is known to label mast cells selectively and quantitatively $(14,15)$. Pretreatment with heparinase prevented mast cell staining. Mast cell granule content was evaluated by measuring fluorescence intensity (expressed in arbitrary units/mast cell) with an image analysis system (Microcomp; Southern Micro Instruments, Atlanta, GA). A significant decrease in fluorescence intensity of mast cells in stimulated sites as compared with those in control sites (PBS treated) was interpreted as degranulation of mast cells during the inflammatory reaction.

5-Lipoxygenase inhibitor study. Mice were treated orally with the 5-lipoxygenase inhibitor A-63162 (30 and $100 \mathrm{mg} / \mathrm{kg})(16)$. The drug was given at $1-\mathrm{h}$ intervals (three doses) before the injection of the $A b$, and at 1.5-h intervals during the challenge period. We have shown that the doses of A- 63162 used cause a dose-dependent inhibition of leukotriene formation in immune complex peritonitis (17).

\section{Results}

$P M N$ influx. Reverse Arthus reaction in the skin of $+/+$ mice as well as in the mast cell-deficient $\mathrm{W} / \mathrm{W}^{\mathrm{v}}$ mice induced $\mathrm{PMN}$ infiltration which was dose dependent with regard to the amount of $\mathrm{Ab}$ injected (Fig. 1). With the lowest dose of $\mathrm{Ab}$ used, $10 \mu \mathrm{g} / \mathrm{site}$, PMN influx was insignificant and was similar to that observed in mice treated only with $100 \mu \mathrm{g} \mathrm{Ab} /$ site but no antigen (i.v.) (data not shown). As expected, no PMN were detected in skin which was only treated with PBS and only very few when the mice were treated with $100 \mu \mathrm{g} \mathrm{Ab} /$ site but not with antigen. The time course of leukocyte influx was established (Fig. 1). In both groups of mice a significant number of PMN was observed at $4 \mathrm{~h}$ (the first time point tested), and maximum was reached by $8 \mathrm{~h}$ after challenge. However, with both doses of $\mathrm{Ab}(30$ and $100 \mu \mathrm{g} / \mathrm{site})$ and at every time point tested, the PMN density in $\mathrm{W} / \mathrm{W}^{\mathrm{v}}$ was significantly lower than in $+/+$ mice. At the maximum $(8 \mathrm{~h}), \mathrm{PMN}$ infiltration in $\mathrm{W} / \mathrm{W}^{\mathrm{v}}$ mice was only $40 \%$ of that in $+/+$ mice. The marked difference between the two sets of mice was quite striking and is illustrated in Fig. 2.

Edema and hemorrhage. The immune complex-mediated reaction was also accompanied by edema and hemorrhage. Edema, evaluated as skin thickness, was dose dependent with regard to antibody (Fig. 3). No edema was observed with $10 \mu \mathrm{g}$ $\mathrm{Ab} /$ site or if only $\mathrm{Ab}, 100 \mu \mathrm{g} / \mathrm{site}$, but not antigen (i.v.) was administered. There was significantly less edema in the mast cell-deficient than in $+/+$ mice (Fig. 3). In $+/+$ mice, with 100 $\mu \mathrm{g}$ of Ab significant edema was already noticed at $4 \mathrm{~h}$ (data not shown) and was maximum at $8 \mathrm{~h}$. With $30 \mu \mathrm{g}$ of $\mathrm{Ab}$, edema was evident only at 8 and $10 \mathrm{~h}$. In $W / W^{v}$ mice, measurable edema could be observed starting at $6 \mathrm{~h}$ (data not shown), with the peak at $8 \mathrm{~h}$ with $100 \mu \mathrm{g}$ of $\mathrm{Ab}$ and only at 8 and $10 \mathrm{~h}$ with $30 \mu \mathrm{g}$ of $\mathrm{Ab}$. Hemorrhage was most pronounced with $100 \mu \mathrm{g}$ of $\mathrm{Ab}$, reached maximum at $8 \mathrm{~h}$ (Fig. 4) and was absent with $10 \mu \mathrm{g}$ $\mathrm{Ab} /$ site or if only $\mathrm{Ab}, 100 \mu \mathrm{g} /$ site, was given and no antigen, i.v. Similar to the other parameters studied, hemorrhage was significantly less in $\mathrm{W} / \mathrm{W}^{\mathrm{v}}$ than in $+/+$ mice (Fig. 4).

Mast cell reconstitution of $W / W^{\nu}$ mice. The experiments described above indicate that all three parameters of inflammation evaluated were significantly reduced in $W / W^{v}$ mice. To confirm that the differences observed were due to the mast cell deficiency and not due to some other abnormality of these mice, certain areas of the skin were repleted with mast cells (>98\% purity). Therefore, only the mast cell deficiency was corrected $(7,12)$. The cultured mast cells injected i.d. into $\mathrm{W} / \mathrm{W}^{\mathrm{v}}$ mice were mucosal-like and stained only with alcian blue and not with safranin $O$. Histological examination after

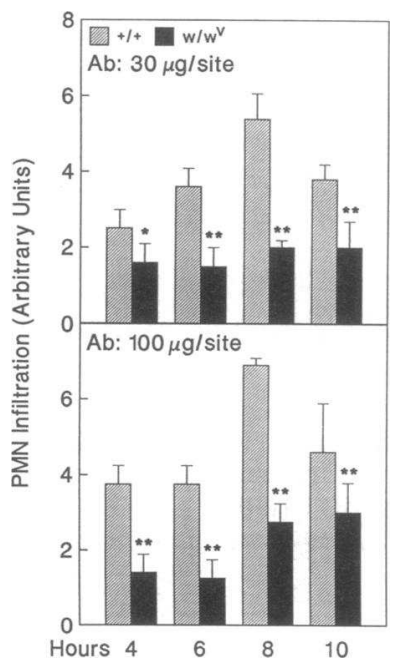

Figure 1. Time course of PMN infiltration in reverse Arthus reaction. Mice were treated with ovalbumin, $20 \mathrm{mg} / \mathrm{kg}$ i.v., and with anti-ovalbumin antibody i.d. At the time indicated after the injection of $\mathrm{Ab}$, skin specimen were fixed and serial sections stained with hematoxylin and eosin were examined microscopically. Arbitrary units were used to evaluate the extent of PMN influx because the PMN infiltration with $100 \mu \mathrm{g} /$ site of $\mathrm{Ab}$ in $+/+$ mice was too dense to perform actual cell counts. There was no PMN infiltration in PBS-injected sites of mice treated i.v. with ovalbumin. PMN influx in $+/+$ mice given $100 \mu \mathrm{g} \mathrm{Ab} /$ site but no ovalbumin was $0.75 \pm 0.2, n=3$, at $8 \mathrm{~h}$. Data are expressed as mean $\pm \mathrm{SD}, n=5$, ${ }^{*} P<0.02,{ }^{* *} P<0.001$. 

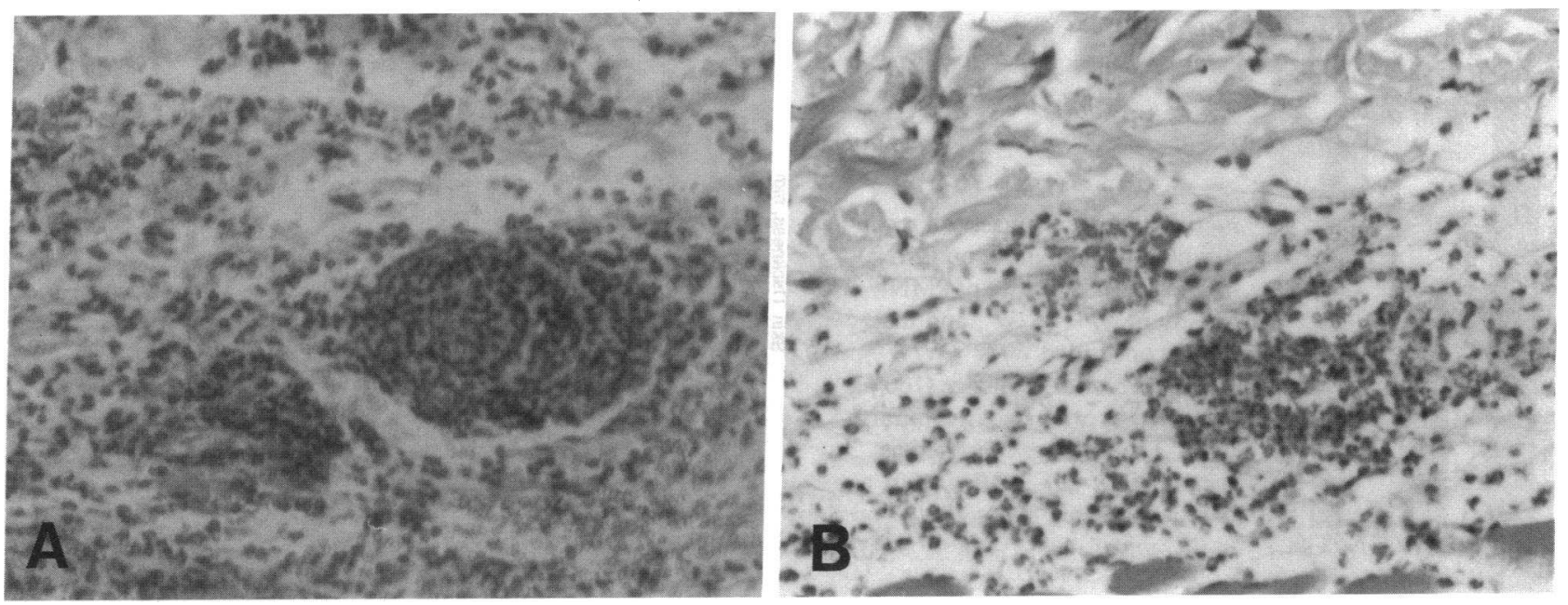

Figure 2. Effect of mast cell deficiency on PMN infiltration. Mice were challenged with ovalbumin i.v., and $100 \mu \mathrm{g} / \mathrm{site}$ of anti-ovalbumin antibody i.d. for $8 \mathrm{~h}$. Representative photomicrographs (10× objective) of skin sections from $(A)+/+$ mice and $(B) \mathrm{W} / \mathrm{W}^{\mathrm{v}}$ mice.

mast cell reconstitution showed, that similar to normal skin, a significant number of mast cells was found in the vicinity of blood vessels. The staining pattern of the injected mast cells had changed, and some of them were now not only alcian blue but also safranin $\mathrm{O}$ positive, indicating differentiation to connective tissue mast cells (data not shown). In these mast cell-reconstituted $\mathrm{W} / \mathrm{W}^{\mathbf{v}}$ mice reverse Arthus reaction resulted in PMN infiltration (Fig. 5), edema (Fig. 3) and hemorrhage (Fig. 4) comparable with that in the $+/+$ mice. These findings indicate that mast cells make an important contribution in immune complex-mediated inflammation and augment PMN influx, edema, and hemorrhage.

Mast cell degranulation studies. To further investigate the participation of mast cells in this model of inflammation, the degranulation of mast cells in stimulated sites was studied. This was accomplished by treating the tissue with avidin-FITC, a stain specific for mast cell granules $(14,15)$. Pretreatment with heparinase blocked the fluorescent staining. The involvement of mast cells in this reaction was corroborated by a $70 \%$ decrease in the fluorescence intensity of mast cells in stimulated

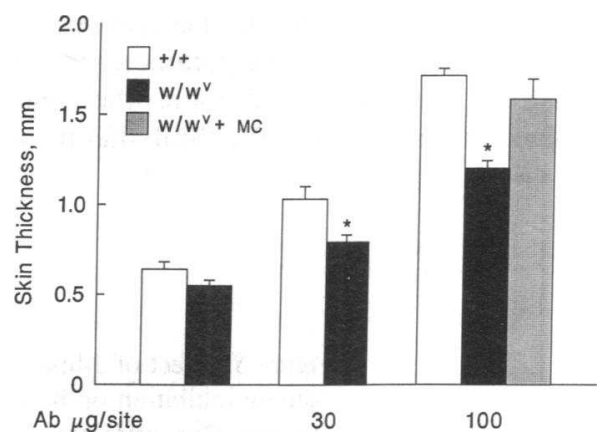

Figure 3. Effect of mast cell deficiency on edema. Skin thickness of $+/+, \mathrm{W} / \mathrm{W}^{\mathrm{v}}$, and mast cell-reconstituted $\mathrm{W} / \mathrm{W}^{\mathrm{v}}\left(\mathrm{W} / \mathrm{W}^{\mathrm{v}}+\mathrm{MC}\right)$ mice was measured $8 \mathrm{~h}$ after $\mathrm{Ab}$ challenge. First set of bars represents PBS-treated sites from the same animals. The skin thickness of animals given $100 \mu \mathrm{g} \mathrm{Ab} /$ site but not antigen was not significantly different from PBS-injected sites $(0.51 \pm 0.01 \mathrm{~mm})$. The data are expressed as mean $\pm \mathrm{SD}, n=3-9,{ }^{*} P<0.01$ as compared with the same dose in $+/+$ mice. skin (PBS control: $180 \pm 9.6, n=160$; stimulated: $54.6 \pm 12.7$ arbitrary units, $n=90$ mast cells, mean $\pm \mathrm{SD}$ ). This indicates that mast cells have lost a large portion of their granules during the inflammatory reaction.

Effect of 5-lipoxygenase inhibition. It is known that leukotrienes are released in inflammation, including immune complex reaction (18-20). $\mathrm{LTB}_{4}$ is a potent chemotactic factor for $\mathrm{PMN}$, and $\mathrm{LTC}_{4}$ and $\mathrm{D}_{4}$ can cause plasma exudation. We tested the involvement of leukotrienes in reverse Arthus reaction by pretreating mice with the 5-lipoxygenase antagonist A-63162. In $+/+$ mice, this compound $(100 \mathrm{mg} / \mathrm{kg})$ caused a $40 \%$ decrease in PMN infiltration (Fig. $6 \mathrm{~A}$ ). No significant effect was observed with $30 \mathrm{mg} / \mathrm{kg}$ (data not shown). In the mast cell-deficient mice, no significant reduction in PMN density occurred with either of the doses of A-63162 tested. To improve the accuracy of these experiments, actual PMN counts were performed on the sections from $W / W^{v}$ mice (Fig. 6 $B)$. Furthermore, A-63162 inhibited edema (Fig. 7) only in $+/+$ but not in $\mathrm{W} / \mathrm{W}^{\mathrm{v}}$ mice. The 5 -lipoxygenase inhibitor also significantly decreased hemorrhage in $+/+$ mice. The effect of this drug on hemorrhage in $\mathrm{W} / \mathrm{W}^{\mathrm{v}}$ mice was difficult to interpret due to the high variability observed (Fig. 8). A-63162 had no effect on mast cell degranulation. The fluorescence intensity of mast cells, reflecting granule content, after challenge with

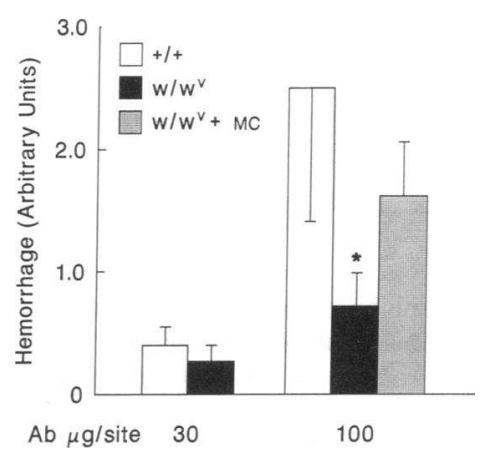

Figure 4. Effect of mast cell deficiency on hemorrhage. Hemorrhage was evaluated in arbitrary units $8 \mathrm{~h}$ after challenge in $+/+, W / W^{v}$, and mast cell-reconstituted $\mathrm{W} / \mathrm{W}^{\mathrm{v}}\left(\mathrm{W} / \mathrm{W}^{\mathrm{v}}+\mathrm{MC}\right)$ mice. The data are expressed as mean $\pm \mathrm{SD}, n$ $=3-9,{ }^{*} P<0.001$ as compared with $+/+$ or $\mathrm{W} / \mathrm{W}^{\mathrm{v}}$ $+\mathrm{MC}$ mice. No hemorrhage was observed in mice injected with antigen i.v. and $10 \mu \mathrm{g} \mathrm{Ag} /$ site or PBS i.d., and in mice given $100 \mu \mathrm{g} \mathrm{Ab} /$ site but no antigen i.v. 


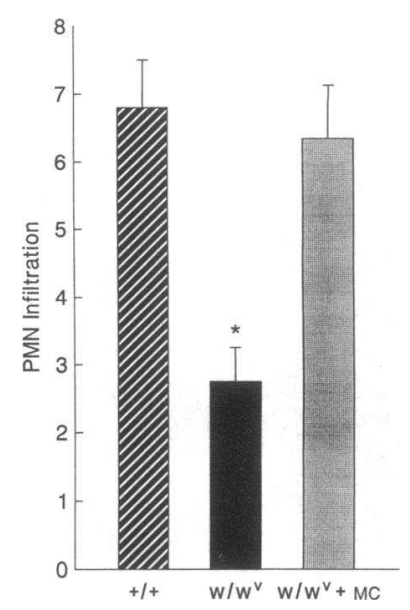

Figure 5. Effect of mast cell reconstitution of $\mathrm{W} / \mathrm{W}^{\mathrm{v}}$ mice on $\mathrm{PMN}$ infiltration. The degree of PMN density in $+/+, W / W^{v}$, and mast cell-reconstituted $\mathrm{W} / \mathrm{W}^{\mathrm{v}}\left(\mathrm{W} / \mathrm{W}^{\mathrm{v}}\right.$ $+\mathrm{MC}) 8 \mathrm{~h}$ after challenge (100 $\mu \mathrm{g}$ $\mathrm{Ab} / \mathrm{site}$ ) was evaluated in arbitrary units. The data are expressed as mean $\pm \mathrm{SD}, n=3-9,{ }^{*} P<0.001$ as compared with $+/+$ and $\mathrm{W} / \mathrm{W}^{\mathbf{v}}$ $+\mathrm{MC}$ mice.

antibody was $54.9 \pm 5.4, n=77$, for skin from animals pretreated with A-63162 and 54.6 \pm 12.7 arbitrary units, $n=90$, without drug pretreatment. This constitutes a 77 and $70 \%$ reduction in mast cell granule content, respectively. These data suggest that leukotrienes released by mast cells participate in this inflammatory reaction. To confirm this possibility, the inhibitor studies were repeated in mast cell-reconstituted $\mathrm{W} / \mathrm{W}^{\mathrm{v}}$ mice. After mast cell repletion A-63162 inhibited PMN influx (Fig. $6 C$ ), edema (Fig. 7) and hemorrhage (Fig. 8) in W/W mice to a similar extent as in $+/+$ mice. Therefore, leukotrienes released by mast cells seem to play an important role in immune complex-mediated inflammation.

\section{Discussion}

The present study demonstrates that mast cells significantly enhance the acute inflammatory processes, such as PMN infiltration, hemorrhage, and edema in immune complex-induced injury. The reaction seemed to be due to immune complex formation because only minor PMN influx and no edema or hemorrhage were detected in mice which were treated only with $100 \mu \mathrm{g} \mathrm{Ab} /$ site for $8 \mathrm{~h}$, but not with antigen. The reduction of the inflammatory parameters observed in $\mathrm{W} / \mathrm{W}^{\mathbf{v}}$ mice was due to their mast cell deficiency and not to other abnormalities.

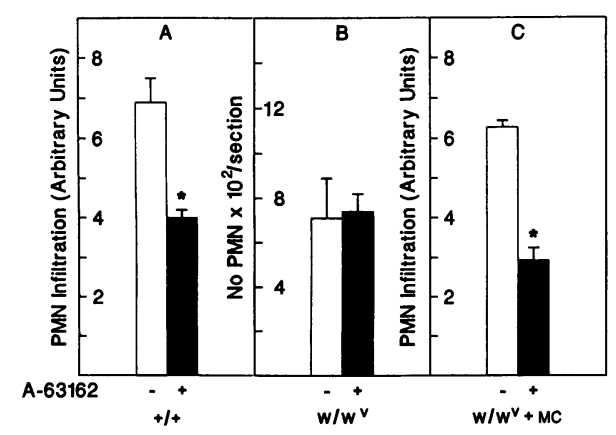

Figure 6. Effect of 5-lipoxygenase inhibition on PMN infiltration. Mice were pretreated with A- $63162,100 \mathrm{mg} / \mathrm{kg}$, as described in Methods, and challenged (100 $\mu \mathrm{g} \mathrm{Ab/site)} \mathrm{for} 8 \mathrm{~h}$. PMN infiltration was evaluated in arbitrary units in $+/+(A)$ and mast cell-reconstituted $\mathrm{W} / \mathrm{W}^{\mathrm{v}}\left(\mathrm{W} / \mathrm{W}^{\mathrm{v}}+\mathrm{MC}\right)(C)$ mice, and by counting the number of $\mathrm{PMN} /$ section in $\mathrm{W} / \mathrm{W}^{\mathrm{v}}$ mice $(B)$. The data are expressed as mean $\pm \mathrm{SD}, n=4,{ }^{*} P<0.001$ as compared with the respective control (no A-63162).

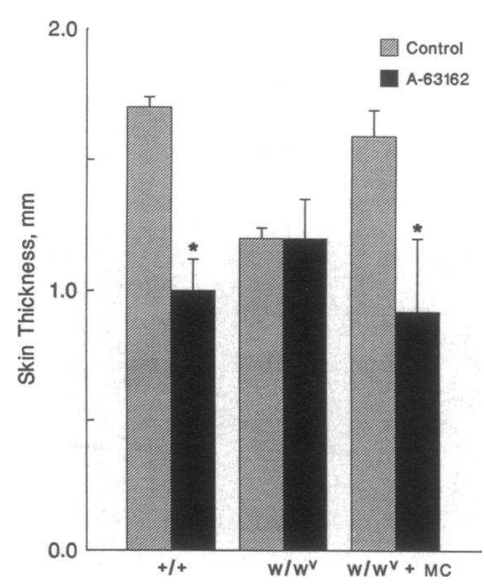

Figure 7. Effect of 5-lipoxygenase inhibition on edema. Mice were pretreated with A-63162, 100 $\mathrm{mg} / \mathrm{kg}$, and challenged (100 $\mu \mathrm{g} \mathrm{Ab} /$ site) for $8 \mathrm{~h}$. The data are expressed as mean $\pm \mathrm{SD}, n=4,{ }^{*} P$ $<0.001$ as compared with the respective control (no A-63162).

After the adoptive transfer of mast cells ( $>98 \%$ purity) into the skin of $\mathrm{W} / \mathrm{W}^{\mathrm{v}}$ mice $\mathrm{PMN}$ infiltration, hemorrhage, and edema were equivalent to that in congenic controls.

The participation of mast cells in reverse Arthus reaction was further substantiated by mast cell degranulation studies. There was a significant reduction in florescence intensity of mast cells stained with avidin-FITC (specific for mast cell granules) after immune complex stimulation. A $70 \%$ decrease in fluorescence intensity suggests an extensive mast cell release reaction. The method used probably underestimates the magnitude of granule loss because completely degranulated mast cells cannot be detected. Evidence of mast cell degranulation in the hamster cheek pouch due to immune complexes has been reported by Bjork and Smedegard (21). We have observed earlier in immune complex-mediated peritonitis that mast cell release preceded leukocyte influx (7).

Upon activation mast cells release several important inflammatory mediators including leukotrienes. $\mathrm{LTB}_{4}$ is a potent chemotactic agent for PMN (22). $\mathrm{LTC}_{4}$ and $\mathrm{D}_{4}$ can cause extravasation of macromolecules (23). $\mathrm{LTB}_{4}$ and $\mathrm{LTC}_{4}$ also seem to act on endothelial cells to promote PMN adhesion $(24,25)$. We tested the involvement of leukotrienes in reverse Arthus reaction by treating the mice with the 5-lipoxygenase inhibitor A-63162. This resulted in a decrease in PMN density, edema and hemorrhage in $+/+$ but not in $W / W^{v}$ mice. The effect of A-63162 was restored upon adoptive transfer of mast cells to $\mathrm{W} / \mathrm{W}^{\mathrm{v}}$ mice. These results suggest that leukotrienes released by mast cells contribute to these inflammatory parameters. It is also possible that mast cell mediators acted upon other cells which in turn synthesized the eicosanoids. We think that mast

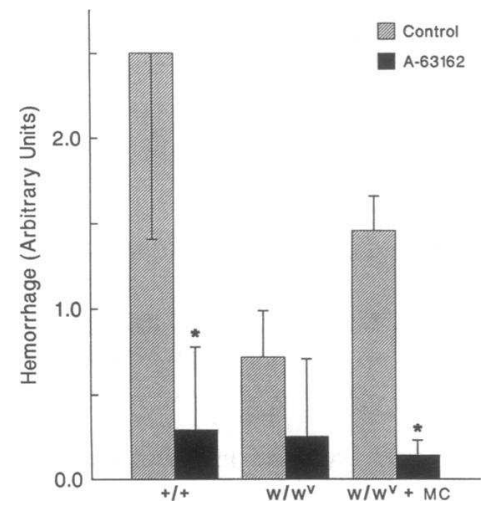

Figure 8. Effect of 5-lipoxygenase inhibition on hemorrhage. Mice were pretreated with A-63162, 100 $\mathrm{mg} / \mathrm{kg}$, and challenged (100 $\mu \mathrm{g} \mathrm{Ab} / \mathrm{site})$ for $8 \mathrm{~h}$. The data are expressed as mean $\pm \mathrm{SD}, n=4,{ }^{*} P$ $<0.001$ as compared with the respective controls (no A-63162). 
cells are probably the source of the leukotrienes in question for the following reasons. Only a few cell types (macrophages, monocytes, mast cells, neutrophils, and eosinophils) produce appreciable amounts of leukotrienes. The cells calling in the PMN have to be in the tissue in a significant number. This narrows the cell source down to mast cells and macrophages. The 5-lipoxygenase inhibition studies would then suggest that mast cells generate the leukotrienes or stimulate macrophages to synthesize these mediators. In an earlier study we investigated the interaction of mast cells and macrophages in the production of eicosanoids. IgE-sensitized mast cells were challenged with antigen in the presence of macrophages or alone. Mast cells released $\mathrm{LTC}_{4}, \mathrm{LTB}_{4}, \mathrm{PGD}_{2}$, and TXB $\mathrm{TH}_{2}$. The macrophages contributed $\mathrm{PGE}_{2}, 6$-keto-PGF $\mathrm{PG}_{1 \alpha}$, and $\mathrm{TXB}_{2}$, but not leukotrienes $(26,27)$. These observations suggest that mast cells may be the source of the leukotrienes which elicit PMN in reverse Arthus reaction. The 5-lipoxygenase inhibitor did not only block PMN infiltration and edema, two well-established functions of leukotrienes, but also hemorrhage. The latter effect of A-63162 was probably due to the decrease in PMN accumulation. Activation of PMN will lead to release of lysosomal enzymes which can cause tissue damage. PMN will discharge these enzymes when exposed to immune complexes (28).

The difference in the effect of the 5-lipoxygenase inhibitor in the two sets of mice may seem rather surprising. Various leukocytes, including macrophages and PMN, can synthesize leukotrienes (29-31); and these cells can be stimulated by immune complexes $(30,32)$. We interpret the data of the present study to mean that the strategic location of mast cells near blood vessels makes these cells critical for the production of leukotrienes which mediate certain early inflammatory effects. The apparent importance of mast cells in close proximity to blood vessels was also suggested by an earlier study (33). We observed in thioglycollate-induced peritonitis that the mere presence of mast cells in the peritoneal cavity of $\mathrm{W} / \mathrm{W}^{\mathrm{v}}$ mice was not sufficient to restore the PMN infiltration to levels comparable to those in $+/+$ mice. Approximately 2 wk of mast cell reconstitution were necessary for complete normalization of the PMN influx. The gradual recovery of the PMN response paralleled the time course of mast cell migration into the tissue, presumably close to blood vessels. In the present study we actually identified mast cells in the vicinity of blood vessels in $\mathrm{W} / \mathrm{W}^{\mathrm{v}}$ mice after adoptive transfer of mast cells. These findings suggest that the presence of mast cells in the proper location in the tissue, i.e., near blood vessels, is essential for their function in inflammation.

In immune complex peritonitis we observed that $100 \mathrm{mg} /$ $\mathrm{kg}$ of A-63162 blocked leukotriene formation by $90 \%$ (17). In the present study, $100 \mathrm{mg} / \mathrm{kg}$ of A-63162 inhibited leukocyte influx only by $40 \%$ and edema by $60 \%$. Makino et al. (19) and Tanaka et al. (18) also observed only a partial inhibition of leukocyte influx and plasma exudation in immune complexinduced pleurisy in the rat after treatment with a 5-lipoxygenase antagonist. Therefore, mediators other than leukotrienes are also involved in these processes. Histamine has been shown to cause plasma exudation. Antihistamines will decrease plasma leakage during immune complex reactions (34). It has recently been reported that mast cells upon stimulation with a number of agents, including IgE/Ag, calcium ionophore, and PMA, will cause the induction of various cytokines, such as IL-1, IL-3, IL-4, IL-6, GM-CSF, and TNF $\alpha$ (35-37). These factors can modulate numerous inflammatory processes. IL-1 and TNF $\alpha$ are known to act on endothelial cells and to cause the expression of ICAM-1 and ELAM-1, which are adhesion molecules for leukocytes $(38,39)$. It has been shown by Klein and his colleagues (40) that mast cell degranulation was associated with the expression of ELAM-1 in venular endothelial cells of human skin organ culture. TNF $\alpha$ seemed to mediate this process because it was blocked by antibodies to this agent. IL-3, IL-4, and GM-CSF stimulate mast cell proliferation. IL1, IL-4, and IL-6 regulate immunoglobulin production which could influence immune complex-mediated inflammation. Other function in inflammation that are modulated by some of these cytokines are eicosanoid production, clotting, wound repair, angiogenesis, and fibrosis (41). Platelet-activating factor is another mediator released by mast cells as well as other proinflammatory cells. It is known to elicit and activate neutrophils (42).

It is well established that the complement pathway is activated in immune complex reactions, and that some of the peptides generated are chemotactic for PMN. Lysosomal enzymes released by $P M N$ can produce increases in vascular permeability. Decomplementation abolishes or reduces the inflammatory process caused by immune complexes (1). This is not in contradiction to our findings. Mast cell activation may have been initiated by complement derived peptides (43). It is also possible that immune complexes acted directly on mast cells. Their activation by antigen-antibody complexes due to binding to the Fc $\gamma$ receptors present on these cells has been reported $(44,45)$. However, mast cell deficiency did not completely inhibit PMN influx and edema. The reaction still present in $\mathrm{W} / \mathrm{W}^{\mathrm{v}}$ mice may be due the action of complement on PMN and the vasculature and/or the activation of another cell type.

Our findings of mast cell involvement in Arthus reaction support earlier evidence implicating mast cells in the pathogenesis of diseases in which immune complexes are known to be deposited in various tissues. An increase in the number of mast cells has been observed in affected skin areas of scleroderma (46), the synovium of rheumatoid arthritis (47), interstitium of fibrotic lung (48), in systemic lupus erythematosus, mixed connective tissue diseases, and other related inflammatory conditions (47). In some of these conditions mast cell activation and an increase in mast cell releasability has been observed (46). In addition to these autoimmune conditions, mast cells may also contribute to inflammatory processes in diseases with immune complexes involving exogenous antigens. Immune complexes are thought to be responsible for some of the manifestations in infectious diseases such as bacterial endocarditis, disseminated gonorrhea, streptococcal infections, dengue hemorrhagic fever, viral hepatitis, dermatophytid reaction, and others (49).

In conclusion, the data presented indicate that mast cells make a significant contribution to immune complex-mediated inflammation. Mast cell deficiency greatly reduced the inflammatory response. Adoptive transfer of mast cells into $\mathrm{W} / \mathrm{W}^{\mathrm{v}}$ mice increased PMN immigration, edema, and hemorrhage to levels comparable with those in congenic controls. The inflammatory reaction was accompanied by an extensive degranulation of mast cells. The 5-lipoxygenase inhibitor A-63162 partially blocked the expression of the three parameters evaluated in $+/+$ but not in $W / W^{v}$ mice. Mast cell reconstitution of $\mathrm{W} / \mathrm{W}^{\mathrm{v}}$ mice restored the effect of A-63162. Therefore, mast cells and their mediators, especially leukotrienes, are necessary for the full expression of immune complex-induced inflammation. These studies have important implications for diseases involving immune complex formation. 


\section{Acknowledgments}

This work was supported by National Institutes of Health grant HL31922.

\section{References}

1. Ranadive, N. S., and H. Z. Movat. 1979. Tissue injury and inflammation induced by immune complexes. In Inflammation, Immunity and Hypersensitivity. H. Z. Movat, editor. Harper \& Row, Inc., New York. 409-443.

2. Galli, S. J., and Y. Kitamura. 1987. Animal model of human disease. Genetically mast-cell-deficient $\mathrm{W} / \mathrm{W}^{\mathrm{v}}$ and $\mathrm{Sl} / \mathrm{Sl}^{\mathrm{d}}$ mice. Their value for the analysis of the roles of mast cells biologic responses in vivo. Am. J. Pathol. 127:191198.

3. Wershil, B. K., Y. A. Mekori, T. Murakami, and S. J. Galli. 1987. ${ }^{125}$ I-Fibrin deposition in IgE-dependent immediate hypersensitivity reactions in mouse skin. Demonstration of the role of mast cells using genetically mast cell-deficient mice locally reconstituted with cultured mast cells. J. Immunol. 139:2605-2614.

4. Wershil, B. K., T. Murakami, and S. J. Galli. 1988. Mast cell-dependent amplification of an immunologically nonspecific inflammatory response. Mast cells are required for the full expression of cutaneous acute inflammation induced by phorbol 12-myristate-13-acetate. J. Immunol. 140:2356-2360.

5. Yano, H., B. K. Wershill, N. Arizono, and S. J. Galli. 1989. Substance P-induced augmentation of cutaneous vascular permeability and granulocyte infiltration in mice is mast cell dependent. J. Clin. Invest. 84:1276-1286.

6. Qureshi, R. A., and B. A. Jakschik. 1987. Role of mast cells in inflammation. Fed. Proc. 46:985.

7. Ramos, B. F., R. Qureshi, K. M. Olsen, and B. A. Jakschik. 1990. The importance of mast cells for the neutrophil influx in immune complex-induced peritonitis in mice. J. Immunol. 145:1868-1873.

8. Van den Broek, M. F., W. B. van den Berg, and L. B. A. van de Putte. 1988. The role of mast cells in antigen induced arthritis in mice. J. Rheumatol. 15:544551.

9. Kitamura, Y., S. Go, and K. Hatanaka. 1978. Decrease of mast cells in $\mathrm{W} / \mathrm{W}^{\mathrm{v}}$ mice and their increase by bone marrow transplantation. Blood. 52:447452.

10. Chervenick, P. A., and D. R. Boggs. 1969. Decreased neutrophils and megakaryocytes in anemic mice of genotype W/Wv. J. Cell. Physiol. 73:25-30.

11. Ebbe, S., E. Phalen, and F. Stohlman, Jr. 1973. Abnormalities of megakaryocytes in W/W mice. Blood. 42:857-864.

12. Nakano, T., T. Sonoda, C. Hayashi, A. Yamatodani, Y. Kanayama, T. Yamamura, H. Asai, T. Yonezawa, Y. Kitamura, and S. J. Galli. 1985. Fate of bone marrow-derived cultured mast cells after intracutaneous, intraperitoneal, and intravenous transfer into genetically mast cell-deficient $\mathrm{W} / \mathrm{W}^{\mathbf{v}}$ mice. Evidence that cultured mast cells give rise to both connective tissue-type and mucosal mast cells. J. Exp. Med. 162:1025-1043.

13. Wei, Y., K. Heghinian, R. L. Bell, and B. A. Jakschik. 1986. Contribution of macrophages to immediate hypersensitivity reaction. J. Immunol. 137:19932000.

14. Bergstresser, P. R., R. E. Tigelaar, and M. D. Tharp. 1984. Conjugated avidin identifies cutaneous rodent and human mast cells. $J$. Invest. Dermatol. 83:214-218

15. Tharp, M. D., L. L. Seelig, Jr., R. E. Tigelaar, and P. R. Bergstresser. 1985. Conjugated avidin binds to mast cell granules. J. Histochem. Cytochem. 33:2732.

16. Summers, J. B., B. P. Gunn, J. G. Martin, H. Mazdiyasni, A. O. Stewart, P. R. Young, A. M. Goetze, J. B. Bouska, R. D. Dyer, D. W. Brooks, and G. W. Carter. 1988. Orally active hydroxamic acid inhibitors of leukotriene biosynthesis. J. Med. Chem. 31:3-5.

17. Ramos, B. F., Y. Zhang, R. Qureshi, and B. A. Jakschik. 1991. Mast cells are critical for the production of leukotrienes responsible for neutrophil recruitment in immune complex-induced peritonitis in mice. J. Immunol. In press.

18. Tanaka, K., A. Ueno, and M. Katori. 1986. Roles of leukotrienes in two rat allergic inflammatory models: IgE-mediated and IgG-antigen complex-induced pleurisies. Prostaglandins. 31:1099-1116.

19. Makino, H., Y. Ashida, T. Saijo, H. Kuriki, S. Terao, Y. Maki. 1986. Role of leukotrienes in rat reversed passive Arthus pleurisy and the effect of AA-861, a 5-lipoxygenase inhibitor. Int. Arch. Allergy Appl. Immunol. 79:38-44.

20. Weichman, B. M., J. W. Berkenkopf, C. A. Cullinan, and R. J. Sturm. 1987. Leukotriene $B_{4}$ production and pharmacologic regulation of reverse passive Arthus pleurisy: importance of antigen dose. Agents Actions. 21:351-354.

21. Bjork, J., and G. Smedegärd. 1984. The microvasculature of the hamster cheek pouch as a model for studying acute immune-complex-induced inflammatory reactions. Int. Arch. Allergy Appl. Immunol. 74:178-185.

22. Ford-Hutchinson, A. W., M. A. Bray, M. V. Doig, M. E. Shipley, and M. J. H. Smith. 1980. Leukotriene B, a potent chemokinetic and aggregating substance released from polymorphonuclear leukocytes. Nature (Lond.). 286:264-265.
23. Dahlen, S.-E., J. Bjork, P. Hedqvist, K. E. Arfors, S. Hammarstrom, J.-A Lindgren, and B. Samuelsson. 1981. Leukotrienes promote plasma leakage and leukocyte adhesion in postcapillary venules: in vivo effects with relevance to the acute inflammatory response. Proc. Natl. Acad. Sci. USA. 78:3887-3891.

24. Hoover, R. L., M. J. Karnovsky, K. F. Austen, E. J. Corey, and R. A. Lewis. 1984. Leukotriene $B_{4}$ action on endothelium mediates augmented neutrophil/endothelial adhesion. Proc. Natl. Acad. Sci. USA. 81:2191-2193.

25. McIntyre, T. M., G. A. Zimmerman, and S. M. Prescott. 1986. Leukotrienes $\mathrm{C}_{4}$ and $\mathrm{D}_{4}$ stimulate human endothelial cells to synthesize platelet-activating factor and bind neutrophils. Proc. Natl. Acad. Sci. USA. 83:2204-2208.

26. Wei, Y., K. Heghinian, R. L. Bell, and B. A. Jakschik. 1986. Contribution of macrophages to immediate hypersensitivity reaction. J. Immunol. 137:1993 2000.

27. Jakschik, B. A., T. A. Rengers, and J. R. Pinski. 1987. Nature of the mast cell-macrophage interaction in immediate hypersensitivity. Adv. Prostaglandin Thromboxane Leukotriene Res. 17:180-185.

28. Weissmann, G., R. B. Zurier, P. J. Spieler, and I. M. Goldstein. 1971. Mechanisms of lysosomal enzyme release from leukocytes exposed to immune complexes and other particles. J. Exp. Med. 134:149-165.

29. Borgeat, P., and B. Samuelsson. 1979. Metabolism of arachidonic acid in polymorphonuclear leukocytes. J. Biol. Chem. 25:7865-7869.

30. Bonney, R. J., P. Naruns, P. Davies, and J. L. Humes. 1979. Antigen-antibody complexes stimulate the synthesis and release of prostaglandins by mouse peritoneal macrophages. Prostaglandins. 18:605-616.

31. Rouzer, C. A., W. A. Scott, Z. A. Cohn, P. Blackburn, and J. M. Manning 1980. Mouse peritoneal macrophages release leukotriene $C$ in response to a phagocytic stimulus. Proc. Natl. Acad. Sci. USA. 77:4928-4932.

32. Ward, P. A., R. E. Duque, M. C. Sulavik, and K. J. Johnson. 1983. In vitro and in vivo stimulation of rat neutrophils and alveolar macrophages by immune complexes. Am. J. Pathol. 110:297-309.

33. Qureshi, R., and B. A. Jakschik. 1988. The role of mast cells in thioglycollate-induced inflammation. J. Immunol. 141:2090-2096.

34. Bjork, J., and G. Smedegard. 1987. Immune-complex-induced inflammatory reaction studied by intravital microscopy: role of histamine and arachidonic acid metabolites. Inflammation. 11:47-58.

35. Young, J. D.-E., C.-C., Liu, G. Butler, Z. A. Cohn, and S. J. Galli. 1987. Identification, purification, and characterization of a mast cell-associated cytolytic factor related to tumor necrosis factor. Proc. Natl. Acad. Sci. USA. 84:91759179.

36. Burd, P. R., H. W. Rogers, J. R. Gordon, C. A. Martin, S. Jayaraman, S. D. Wilson, A. M. Dvorak, S. J. Galli, and M. E. Dorf. 1989. Interleukin 3-dependent and -independent mast cells stimulated with $\mathrm{IgE}$ and antigen express multiple cytokines. J. Exp. Med. 170:245-257.

37. Plaut, M., J. H. Pierce, C. J. Watson, J. Hanley-Hyde, R. P., Nordan, and W. E. Paul. 1989. Mast cell lines produce lymphokines in response to crosslinkage of FceRI or to calcium ionophores. Nature (Lond.). 339:64-67.

38. Kuppner, M. C., E. V. Meir, M. G. Hamou, and N. D. Tribolet. 1990. Cytokine regulation of intercellular adhesion molecule-1 (ICAM-1) expression on human glioblastoma cells. Clin. Exp. Immunol. 81:142-148.

39. Bevilacqua, M. P., J. S. Pober, D. L. Mendrick, R. S. Cotran, and M. A. Gimbrone, Jr. 1987. Identification of an inducible endothelial-leukocyte adhesion molecule. Proc. Natl. Acad. Sci. USA. 84:9238-9242.

40. Klein, L. M., R. M. Lavker, W. L. Matis, and G. F. Murphy. 1989. Degranulation of human mast cells induces an endothelial antigen central to leukocyte adhesion. Proc. Natl. Acad. Sci. USA. 86:8972-8976.

41. Arai, K.-I., F. Lee, A. Miyajima, S. Miyatake, A. Arai, and T. Yokota. 1990. Cytokines: coordinators of immune and inflammatory responses. Annu. Rev. Biochem. 59:783-836.

42. Braquet, P., L. Touqui, T. Y. Shen, and B. B. Vargaftig. 1987. Perspectives in platet-activating factor research. Pharmacol. Rev. 39:97-145.

43. Johnson, A. R., T. E. Hugli and H. J. Muller-Eberhard. 1975. Release of histamine from rat mast cells by the complement peptides $\mathrm{C} 3 \mathrm{a}$ and $\mathrm{C} 5 \mathrm{a}$. Immunology. 28:1067-1080.

44. Daeron, M., A. Prouvost-Danon, and G. A. Voisin. 1980. Mast cell membrane antigens and Fc receptors in anaphylaxis. II. Functionally distinct receptors for IgG and for IgE on mouse mast cells. Cell. Immunol. 49:178-189.

45. Fox, P. C., L. K. Basciano, and R. P. Siraganian. 1982. Mouse mast cell activation and desensitization for immune aggregate-induced histamine release. J. Immunol. 129:314-319.

46. Claman, H. N. 1989. On scleroderma. Mast cells, endothelial cells, and fibroblasts. J. Am. Med. Assoc. 262:1206-1209.

47. Godfrey, H. P., C. Ilardi, W. Engber, and F. M. Graziano. 1984. Quantitation of human synovial mast cells in rheumatoid arthritis and other rheumatic diseases. Arthritis Rheum. 27:852-856.

48. Kawanami, O., V. J. Ferrans, J. D. Fulmer, and R. G. Crystal. 1979. Ultrastructure of pulmonary mast cells in patients with fibrotic lung disorders. Lab. Invest. 40:717-734.

49. Dixon, F. J., C. C. Cochrane, and A. N. Theofilopoulos. 1988. Immune complex injury. In Immunological Diseases. M. Samter, editor. Little, Brown and Co., Boston, MA. 233-259. 